\title{
Influence of microenvironment on cell adhesion, polarization, and migration
}

\author{
This article was published in the following Dove Press journal: \\ International Journal of Nanomedicine \\ 5 July 2012 \\ Number of times this article has been viewed
}

\author{
Ivana Pajic-Lijakovic \\ Milenko Plavsic \\ Faculty of Technology and Metallurgy, \\ University of Belgrade, Belgrade, \\ Serbia
}

We read an interesting article by Torres-Costa et $\mathrm{al}^{1}$ recently published in the International Journal of Nanomedicine. The influence of the rheological behavior of extracellular matrix (ECM) to cell adhesion and migration represents an important issue for various biomedical applications. The nature of cell adhesion and migration are stochastic as reported by Stokes et al. ${ }^{2}$ Cell migration should be considered in subcellular and cellular levels by applying fluctuation-dissipation theorem in the form of Langevin-type force-balance equations, ${ }^{3-5}$ and supercellular level by formulating mesoscopic mass and stress-balance equations. ${ }^{6}$

Torres-Costa et $\mathrm{al}^{1}$ experimentally and theoretically considered cell adhesion and migration as well as cell polarization on silicon surfaces. They developed the model and simulation by including only two basic criteria: (1) the tendency of cells to balance their adherence to the ECM; and (2) the tendency of cells to avoid overlapping with other cells. The authors introduce the concept of "adherence vector modulus." However, the stability of adhesion complexes could not be described only by the adherence vector modulus. For the zero state of the adherence vector modulus, the stability of the adhesion complex must be dependent on conformational changes of ligand-receptor bonds. The changes depend on the ECM surface structure. Small conformational changes of ligand-receptor bonds also influence binding affinity. Bruinsma $^{3}$ formulated the model for consideration of the adhesion complex stability at the subcellular level. He developed stochastic Langevin-type force-balance equations for describing the dynamics of adhesion complex changes. He considered using a viscous drug on the adhesion site, the spring force of bonds, and thermal random noise force. The influence of the rheological behavior of ECM on adhesion complex dynamics is quantified by rheological parameters: viscosity and Young's modulus of elasticity. Bruinsma ${ }^{3}$ described potential and traction forces to explain the influence of conformational changes of adhesion complex on state of actin filaments. Consequently, the stability of adhesion complex should be correlated with structural cytoskeleton changes.

Torres-Costa et $\mathrm{al}^{1}$ experimentally observed structural cytoskeleton changes through the distribution of actin fibers around the nuclei. The distribution of actin fibers is related to the strain energy density of the cytoskeleton and has a feedback action on the adhesion complex. The dynamics of adhesion complex should be correlated with cell polarization on one side and with cell migration on the other. Cell polarization caused by cell interactions with ECM has been described by the force dipoles or the
Correspondence: Ivana Pajic-Lijakovic Faculty of Technology and Metallurgy, University of Belgrade, I I000 Belgrade, Serbia Email iva@tmf.bg.ac.rs 
polarization stress as reported by Bischofs and Schwarz ${ }^{7}$ and Zemel and Safran. ${ }^{8}$ Cell polarization is quantified by cellular susceptibility tensor in the presence of local matrix strain caused by cell traction force. It includes reorganization of cell focal adhesion complex and stress of cytoskeleton. Cell migration at cellular level has been also described by Langevin-type force balance equation. ${ }^{4,5}$ Some authors have determined experimentally the anomalous nature of cell migration dependently on cell type and rheological behavior of ECM. ${ }^{9,10}$ Upadhyaya et al ${ }^{10}$ modified Langevin-type modeling equations and the corresponding Fokker-Planck equation for describing anomalous nature of cell migration by introducing the fraction order derivatives.

Torres-Costa et al $^{1}$ should extend their consideration and quantify the dynamics of cell adhesion, polarization, and migration in the light of basic theories and model parameters. The influence of rheological behavior of ECM to cell adhesion and migration has been quantified by model parameters such as cell mobility tensor, cellular susceptibility tensor, order of fractional derivatives for anomalous nature of cell migration, and particular form of traction force or traction stress. On that basis, readers could be better informed about the mechanisms influencing the structural changes of silicon surfaces on cellular dynamics.

\section{Disclosure}

The authors report no conflicts of interest in this letter.

\section{References}

1. Torres-Costa V, Martínez-Muñoz G, Sánchez-Vaquero V, et al. Engineering of silicon surfaces at the micro- and nanoscales for cell adhesion and migration control. Int J Nanomedicine. 2012;7:623-630.

2. Stokes CL, Lauffenburger DA, Williams SK. Migration of individual microvessel endothelial cells: stochastic model and parameter measurement. J Cell Sci. 1991;99:419-430.

3. Bruinsma R. Theory of force regulation by nascent adhesion sites. Biophys J. 2005;89:87-94.

4. Smith JT, Tomfohr JK, Wells MC, Beebe TP, Kepler TB, Reichert MW. Measurement of cell migration on surface-bound fibronectin gradients. Langmuir. 2004;20:8279-8286.

5. Smith JT, Elkin MT, Reichert MW. Directed cell migration on fibronectin gradients: effects of gradient slope. Exp Cell Res. 2006;312:2424-2432.

6. Murray JD, Maini PK, Tranquillo RT. Mechanochemical models for generating biological pattern and form in development. Physics Reports. 1988;171(2):59-84.

7. Bischofs IB, Schwarz US. Effect of poisson ratio on cellular structure formation. Phys Rev Lett. 2005;95(6):068102.

8. Zemel A, Safran SA. Active self-polarization of contractile cells in asymmetrically shaped domains. Phys Rev E Stat Nonlin Soft Matter Phys. 2007;76(2 Pt 1):021905.

9. Rieu JP, Upadhyaya A, Glazier JA, Ouchi NB, Sawada Y. Diffusion and deformations of single hydra cells in cellular aggregates. Biophys $J$. 2000;79:1903-1914.

10. Upadhyaya A, Rieu JP, Glazier JA, Sawada Y. Anomalous diffusion and non-Gaussian velocity distribution of Hydra cells in cellular aggregates. Physica A. 2001;293:549-558.
International Journal of Nanomedicine

\section{Publish your work in this journal}

The International Journal of Nanomedicine is an international, peerreviewed journal focusing on the application of nanotechnology in diagnostics, therapeutics, and drug delivery systems throughout the biomedical field. This journal is indexed on PubMed Central, MedLine, CAS, SciSearch ${ }^{\circledR}$, Current Contents ${ }^{\circledR} /$ Clinical Medicine,

\section{Dovepress}

Journal Citation Reports/Science Edition, EMBase, Scopus and the Elsevier Bibliographic databases. The manuscript management system is completely online and includes a very quick and fair peer-review system, which is all easy to use. Visit http://www.dovepress.com/ testimonials.php to read real quotes from published authors. 